\title{
ANALISIS KEBIJAKAN PERAWATAN DAN PENENTUAN SISA UMUR HIDUP MESIN INJEKSI PLASTIK DENGAN MENGGUNAKAN METODE RISK BASED MAINTENANCE (RBM) DAN REPLACEMENT ANALYSIS DI CV XYZ
}

\author{
Mohammad Tajudin ${ }^{*}$, Judi Alhilman ${ }^{2}$, Endang Budiasih ${ }^{3}$ \\ Program Studi Teknik Industri, Fakultas Rekayasa Industri, Universitas Telkom \\ Jl. Telekomunikasi Terusan Buah Batu, Bandung 40257 \\ *Email: mohammadtajudin.01@gmail.com
}

\begin{abstract}
ABSTRAK
CV XYZ merupakan perusahaan yang bergerak pada bidang industri pengadaan produk dan penyedia jasa perawatan mold, part, dan injeksi sejak tahun 1987. Salah satu produk spare part yang diproduksi oleh CV XYZ adalah spare part yang berfungsi untuk meminimasi gesekan yang terjadi pada shockbreaker. Mesin injeksi plastik merupakan mesin yang digunakan untuk memproduksi spare part tersebut. Dalam memastikan kondisi dari suatu mesin, peralatan, maupun komponen yang digunakan dalam suatu perusahaan dapat bekerja dengan baik sesuai dengan fungsinya dapat melakukan kegiatan maintenance. Metode perawatan yang digunakan dalam penelitian ini adalah Risk Based Maintenance (RBM) dan Replacement Analysis. Metode RBM merupakan model pemeliharaan berbasis risiko menggunakan historis kegagalan tanpa perlu memperhatikan alasan fisik dari kegagalan yang digunakan untuk mengetahui nilai risiko yang harus diterima perusahaan ketika mesin injeksi plastik mengalami kegagalan. Berdasarkan metode RBM diperoleh nilai risiko sebesar Rp 439,219,486. Metode Replacement Analysis digunakan untuk menentukan kebijakan kapan mesin injeksi harus dilakukan penggantian dan berapa sisa umur hidup dari mesin tersebut. Berdasarkan metode Replacemnet Analysis diperoleh kebijakan waktu penggantian dan sisa umur hidup dari mesin injeksi plastik adalah 7 tahun lagi.
\end{abstract}

Kata kunci: Maintenance, Mesin Injeksi Plastik, RBM, Replacement Analysis.

\section{ABSTRACT}

CV XYZ is a company engaged in the field of industrial procurement of products and provider of maintenance services mold, the part, and injection since 1987. One of the products of spare parts produced by $C V X Y Z$ is a spare part that serves to minimize the friction that occurs on the shockbreaker. Plastic injection machine is a machine used to manufacture spare parts. In ascertaining the condition of a machine, equipment, or components used within a company can work well in accordance with its function can perform maintenance activities. The maintenance method used in this research are Risk Based Maintenance (RBM) and Replacement Analysis. Methods of RBM is a model of maintenance risk-based using failure historical without need to pay attention to the physical reasons of failure used to determine the value of risk that must be accepted by the company when the plastic injection machine failure. Based on the methods of RBM obtained risk value of $R p$ 439,219,486. The method of Replacement Analysis is used to determine policy when the injection machine to do replacement and remaining life of the machine. Based on the method of Replacemnet Analysis obtained policy the time of replacement and remaining life of the plastic injection machines is 7 years.

Keywords: Maintenance, Plastic Injection Machine, RBM, Replacement Analysis. 


\section{PENDAHULUAN}

CV XYZ merupakan perusahaan yang bergerak pada bidang industri pengadaan produk dan penyedia jasa perawatan mold, part, dan injeksi sejak tahun 1987. Salah satu produk spare part yang diproduksi oleh $\mathrm{CV}$ XYZ adalah spare part yang berfungsi untuk meminimasi gesekan yang terjadi pada shockbreaker. Perusahaan yang beroperasi pada bidang Industri biasanya melibatkan aset seperti mesin dalam menjalankan operasi yang ada.

Mesin injeksi plastik merupakan salah satu mesin yang digunakan untuk memproduksi spare part bagian dari shockbreaker di CV XYZ. Mesin injeksi tersebut terdiri dari beberapa tipe yaitu mesin injeksi plastik dengan berat 95 ton, 105 ton, 155 ton, dan 120 ton. Dalam menjalankan proses operasi, mesin dihadapkan pada berbagai risiko yang dapat menghambat berlangsungnya proses operasi, penggunaan mesin secara terus menerus menjadi salah satu penyebab terjadinya kerusakan. Berikut merupakan data frekuensi kerusakan dari masing-masing tipe mesin injeksi plastik dari tahun 2016, 2017, dan 2018:

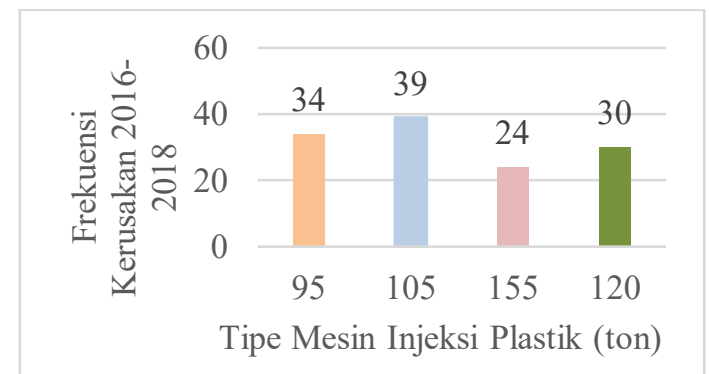

Gambar 1 Data Frekuensi Kerusakan

Berdasarkan data frekuensi kerusakan, mesin injeksi plastik dengan tipe 105 ton mengalami kerusakan yang paling sering, sehingga mesin injeksi plastik tipe 105 ton tersebut akan dijadikan objek dalam penelitian. Dengan adanya kerusakan pada mesin injeksi plastik diperlukan pendekatan untuk mengelola suatu aset/ mesin dengan cara yang aman dan hemat biaya. Salah satu cara yang dapat digunakan adalah dengan melakukan maintenance atau pemeliharaan secara berkala untuk mencegah terjadinya kerusakan ataupun mengatasi kerusakan yang terjadi disuatu perusahaan. Oleh karena itu digunakan model umum untuk memperhitungkan risiko kegagalan di industri dan mengambil keputusan mengenai kebijakan penggantian peralatan yang digunakan oleh perusahaan.

Risk Based Maintenance (RBM) merupakan pendekatan keandalan dan strategi penilaian risiko yang membantu dalam proses pengambilan keputusan mengenai kebijakan perawatan aset (Khalifa, Khan and Thorp, 2015). Dengan metode tersebut dapat diketahui nilai konsekuensi dan risiko yang diterima perusahaan ketika mesin injeksi plastik mengalami kerusakan. Selain itu digunakan metode Replacement Analysis merupakan metode yang digunakan untuk menganalisis suatu fasilitas yang ada dan memperoleh kebijakan apakah fasilitas tersebut harus diganti dengan yang baru atau tidak (Newnan, Eschenbach and Lavelle, 2004). Dengan metode tersebut diperoleh kebijakan perawatan dapat mengetahui sisa umur dari mesin injeksi plastik.

\section{STUDI PUSTAKA}

\section{Maintenance}

Maintenance (Perawatan) merupakan kegiatan yang diperlukan untuk menjaga atau mengembalikan suatu sistem kedalam kondisi semula (kembali dalam kondisi operasi) (Jiang and Murthy, 2008). Perawatan juga didefinisikan sebagai aktivitas yang berfokus untuk memastikan suatu komponen atau sistem dapat digunakan sesuai dengan fungsinya (Alhilman et al., 2015). Perawatan akan sangat penting dalam arti luas dan kebijakannya dalam melakukan perawatan harus ditetapkan dengan benar dan cepat (Nakagawa, 2008).

\section{Perawatan Pencegahan (Preventive Maintenance)}

Preventive Maintenance (PM) merupakan kegiatan perawatan yang dilakukan untuk mencegah terjadinya masalah atau kegagalan (Mobley, Higgins and Wikoff, 2008). Program pemeliharaan preventif menggunakan evaluasi rutin peralatan pabrik, mesin, dan sistem yang penting untuk mendeteksi potensi masalah dan segera menjadwalkan pemeliharaan untuk mencegah degradasi apapun dalam kondisi operasi.

Perawatan Korektif (Corrective Maintenace) Correvtive Maintenance (CM) merupakan kegiatan perawatan yang dilakukan untuk 
memperbaiki masalah atau kegagalan yang terjadi, perbedaan utama antara pemeliharaan korektif dan pencegahan adalah bahwa masalah harus ada sebelum tindakan korektif diambil (Mobley, Higgins and Wikoff, 2008). Tindakan yang dilakukan biasanya seperti perbaikan kecil, pergantian komponen, dan perbaikan besar yang dilakukan secara tidak terjadwal atau tergantung pada kondisi komponen atau sistem tersebut.

\section{Risk Based Maintenance}

Risk Based Maintenance merupakan pendekatan keandalan dan strategi penilaian risiko yang membantu dalam proses pengambilan keputusan mengenai kebijakan perawatan aset untuk menjaga fungsi aset selama beroperasi (Khalifa, Khan and Thorp, 2015).

RBM memiliki tujuan untuk mengurangi risiko yang ditimbulkan akibat kegagalan yang terjadi pada komponen atau sistem saat beroperasi. Dengan menilai tingkat risiko yang disebabkan oleh kegagalan masing-masing komponen dimana komponen yang memiliki risiko tinggi akan diberikan lebih banyak perhatian daripada komponen yang berisiko rendah (Khan and Haddara, 2004). Selain itu Risk Based Maintenance memiliki modul yang berkaitan satu sama lain yaitu estimasi risiko, evaluasi risiko, dan optimasi pemeliharaan. Pada penelitian ini metode RBM hanya berfokus pada modul estimasi risiko dengan menggunakan kegagalan historis tanpa perlu memperhatikan alasan fisik dari kegagalan yang terjadi untuk mengetahui konsekuensi dan risiko akibat kegagalan.

\subsection{Replacement Analysis}

Replacement Analysis merupakan metode yang digunakan untuk menganalisis suatu fasilitas yang ada dan memperoleh kebijakan apakah fasilitas tersebut harus diganti dengan yang baru atau tidak (Giatman, 2006). Tujuan dari Replacement Analysis untuk mengetahui kapan suatu fasilitas, peralatan, atau mesin dilakukan penggantian, dan sisa umurnya.
Dalam perhitungan metode Replacement Analysis menggunakan pendekatan dari Equivalent Uniform Annual Cost (EUAC) merupakan hasil pengeluaran atau cash out dalam tahun. Dalam pengambilan keputusan dilakukan dengan memperhitungkan Total Equivalent Uniform Annual Cost (EUAC) untuk tahun-tahun berikutnya yang kemudian dipilih nilai Total EUAC minimum. Komponen yang terdapat dalam perhitungan Total EUAC adalah EUAC Capital dan EUAC Operational dan Maintenance (Newnan, Eschenbach and Lavelle, 2004).

\section{METODE PENELITIAN}

Model konseptual ini merupakan aliran yang menunjukkan rangkaian konsep pemikiran yang dijadikan sebagai pedoman penelitian agar dapat membantu pencapaian tujuan penelitian dengan mudah. Adapun model konseptual pada penelitian kali ini dapat dilihat pada Gambar 2.

Tahap pertama yang dilakukan yaitu menentukan tipe mesin injeksi plastik yang akan dijadikan objek penelitian berdasarkan frekuensi kerusakan dari tahun 2016 hingga 2018. Kemudian dilanjutkan dengan melakukan penentuan distribusi yang paling mewakili dari data TTF, TTR, dan DT dengan menggunakan uji Anderson-Darling, dan dilanjutkan dengan menentukan parameter dari hasil distribusi yang paling mewakili. Selanjutnya dilakukan perhitungan metode Risk Based Maintenance yang diawali dengan menentukan peluang kegagalan (Pf), dilanjutkan dengan perhitungan konsekuensi yang kemudian dilakukan perkiraan risiko dengan mengkalikan peluang kegagalan dengan konsekuensi kegagalan.

Selain itu dilakukan juga perhitungan metode Replacement Analysis dengan menentukan nilai Total EUAC yang melibatkan EUAC Capital dan EUAC O\&M untuk tahun-tahun berikutnya yang kemudian dipilih Total EUAC pada periode tertentu yang memiliki nilai minimum untuk mendapatkan kebijakan dan sisa umur dari mesin injeksi plastik. 


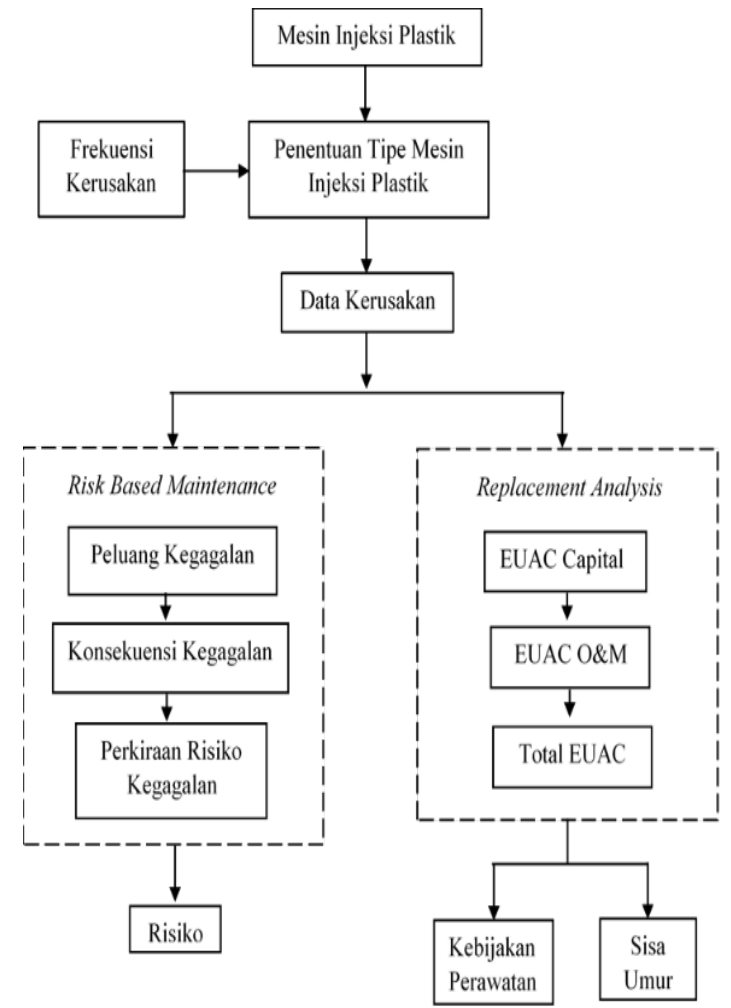

Gambar 2 Metodologi

\section{HASIL DAN PEMBAHASAN}

\subsection{Pengumpulan Data}

Penelitian ini dilakukan dengan mengumpulkan data historis dari kegagalan mesin injeksi plastik yang terdapat pada CV XYZ dari tahun 2016 sampai 2018. Pengumpulan informasi dan data dilakukan dengan cara melihat langsung kondisi mesin, melakukan tanya jawab dan diskusi dengan kepala divisi maintenance.

\subsection{Penentuan Distribusi Time to Failure (TTF), Time to Repair (TTR), dan Downtime (DT)}

Dalam penentuan distribusi dilakukan menggunakan uji Anderson Darling, dengan tujuan untuk memperoleh distribusi yang paling mewakili dari data TTF, TTR, dan DT pada mesin injeksi plastik. Untuk mengetahui distribusi yang paling mewakili dapat diketahui melalui nilai $\mathrm{AD}$ terlebih dahulu, yang merupakan nilai yang menunjukkan apakah suatu distribusi dapat mewakili penyebaran suatu data. Oleh karena itu, semakin kecil nilai $\mathrm{AD}$ yang diperoleh maka semakin mewakili distribusi tersebut terhadap penyebaran data. Kemudian digunakan nilai P-Value untuk mengetahui apakah suatu hipotesis ditolak atau diterima, dimana nilai P-Value harus lebih besar dari $\alpha$. Berikut merupakan hasil penentuan distribusi TTF, TTR, dan DT:
Tabel 1 Penentuan Distribusi Data

\begin{tabular}{|c|c|c|}
\hline Mesin & Data & Distribusi \\
\hline \multirow{4}{*}{ Injeksi Plastik } & Time to Failure & Weibull \\
\cline { 2 - 3 } & Time to Repair & Weibull \\
\cline { 2 - 3 } & Downtime & Weibull \\
\hline
\end{tabular}

\subsection{Penentuan MTTF, MTTR, dan MDT}

Penetuan Mean Time to Failure (MTTF), Mean Time to Repair (MTTR), dan Mean Downtime (MDT) dilakukan berdasarkan distribusi yang terpilih dari masing-masing data TTF, TTR, dan DT. Dalam perhitungan nya melibatkan parameter dari distribusi yang mewakili masing-masing data. Adapun hasil perhitungan MTTF, MTTR, dan MDT sebagai berikut:

Tabel 2 Perhitungan Waktu Rata-rata

\begin{tabular}{|c|c|c|c|c|}
\hline & $\begin{array}{c}\text { Distribu } \\
\text { si }\end{array}$ & \multicolumn{2}{|c|}{ Parameter } & \\
\hline \multirow{2}{*}{$\begin{array}{c}\text { MTT } \\
\text { F }\end{array}$} & \multirow[t]{2}{*}{ Weibull } & $\begin{array}{c}\eta \\
\text { atau } \\
\alpha\end{array}$ & $\begin{array}{c}576.07 \\
7\end{array}$ & \multirow{2}{*}{$\begin{array}{c}694.20906 \\
22\end{array}$} \\
\hline & & $\beta$ & $\begin{array}{c}0.7392 \\
85\end{array}$ & \\
\hline \multirow{2}{*}{$\begin{array}{c}\text { MTT } \\
\text { R }\end{array}$} & \multirow[t]{2}{*}{ Weibull } & $\begin{array}{c}\eta \\
\text { atau } \\
\alpha\end{array}$ & $\begin{array}{c}27.035 \\
5\end{array}$ & \multirow{2}{*}{$\begin{array}{c}36.501884 \\
07\end{array}$} \\
\hline & & $\beta$ & $\begin{array}{c}0.6570 \\
65\end{array}$ & \\
\hline \multirow[t]{2}{*}{ MDT } & \multirow[t]{2}{*}{ Weibull } & $\begin{array}{c}\eta \\
\text { atau } \\
\alpha\end{array}$ & $\begin{array}{c}30.177 \\
2\end{array}$ & \multirow[t]{2}{*}{$\begin{array}{c}37.106133 \\
99\end{array}$} \\
\hline & & $\beta$ & 0.722368 & \\
\hline
\end{tabular}

\subsection{Perhitungan Risk Based Maintenance}

\subsubsection{Peluang Kegagalan}

Perhitungan peluang kegagalan atau analisis kegagalan probabilistik yang terjadi pada mesin injeksi plastik selama satu tahun waktu operasional 7152 jam. Perhitungan peluang kegagalan pada mesin injeksi plastik dengan parameter $\alpha$ (576.077) dan $\beta$ (0.739) sesuai dengan hasil penentuan distribusi yang paling mewakili pada data TTF. Dalam penentuan perluang kegagalan terlebih dahulu dilakukan perhitungan reliability $(\mathrm{Rm})$ dengan persamaan sebagai berikut:

$$
R m(t)=\exp \left[-\left(\frac{t}{\alpha}\right)^{\beta}\right]
$$


Kemudian, nilai reliability $(\mathrm{Rm})$ disubtitusikan dalam persamaan $\mathrm{Pf}=1-\mathrm{Rm}$. Adapun hasil perhitungan dari peluang kegagalan mesin injeksi plastik sebagai berikut:

Tabel 3 Perhitungan Peluang Kegagalan

\begin{tabular}{|c|c|c|c|c|}
\hline \multicolumn{2}{|c|}{ Parameter Distribusi } & Periode & Rm & Pf \\
\cline { 1 - 2 }$\eta$ atau $\alpha$ & $\beta$ & (Jam) & & \\
\hline 576.077 & 0.739 & 7152 & 0.002 & 0.998 \\
\hline
\end{tabular}

\subsubsection{Konsekuensi Kegagalan}

Perhitungan konsekuensi ini dilakukan pada mesin injeksi plastik. Perhitungan konsekuensi bertujuan untuk mengetahui kerugian atau konsekuensi yang diterima perusahaan akibat kegagalan yang terjadi, yang diperoleh dari perhitungan system performance loss. Perhitungan system performance loss (SPL) melibatkan penjumlahan kerugian selama downtime (MDT), engineer cost (EC) selama MTTR, material cost (MC), dan harga mesin (HK). Persamaan yang digunakan sebagai berikut:

$$
S P L=(M D T \times L O R)+(M T T R \times E C)+M C+\mathrm{HK}
$$

Berdasarkan hasil perhitungan diperoleh nilai konsekuensi kegagalan sebagai berikut:

Tabel 4 Konsekuensi Kegagalan

\begin{tabular}{|c|cc|}
\hline Mesin & \multicolumn{2}{|c|}{ System Performance Loss } \\
\hline Injeksi Plastik & $\mathrm{Rp}$ & $439,923,318$ \\
\hline
\end{tabular}

\subsubsection{Perkiraan Risiko Kegagalan}

Perhitungan perkiraan risiko kegagalan (Rf) yang dilakukan pada mesin injeksi plastik ini bertujuan untuk mengetahui risiko yang harus diterima perusahaan yang dikarenakan terjadinya kegagalan diperoleh dari hasil perkalian peluang kegagalan (Pf) dengan system performance loss. Berikut merupakan hasil perhitungan perkiraan risiko:

Tabel 5 Risiko Kegagalan

\begin{tabular}{|c|c|c|}
\hline Pf & $\begin{array}{c}\text { System Performance } \\
\text { Loss }\end{array}$ & $\mathrm{Rf}$ \\
\hline \multirow{2}{*}{0.998} & $\mathrm{Rp}$ & $\mathrm{Rp}$ \\
& $439,923,318$ & $439,219,486$ \\
\hline
\end{tabular}

\subsection{Perhitungan Replacement Analysis}

\subsubsection{EUAC Capital}

Perhitungan Equivalent Uniform Annual Cost Capital ini merupakan nilai modal dari harga mesin pada periode tertentu yang dapat diperoleh melalui perhitungan nilai sisa dari mesin injeksi plastik. Biaya yang dikeluarkan perusahaan untuk medapatkan mesin injeksi plastik adalah sebesar Rp 420,000,000. Setelah pemakaian dari tahun 2013 hingga 2018 (tahun penelitian) diasumsikan mengalami penyusutan sebesar $12.5 \%$ setiap tahunnya. Berikut hasil perhitungan nilai sisa mesin injeksi plastik pada tahun 2018:

Tabel 6 EUAC Capital

\begin{tabular}{|c|c|cc|}
\hline \multicolumn{2}{|c|}{ Harga Beli } & $\mathrm{Rp}$ & $420,000,000$ \\
\hline \multirow{5}{*}{$12.50 \%$} & 2013 & $\mathrm{Rp}$ & $367,500,000$ \\
\cline { 2 - 4 } & 2014 & $\mathrm{Rp}$ & $321,562,500$ \\
\cline { 2 - 4 } & 2015 & $\mathrm{Rp}$ & $281,367,188$ \\
\cline { 2 - 4 } & 2016 & $\mathrm{Rp}$ & $246,196,289$ \\
\cline { 2 - 4 } & 2017 & $\mathrm{Rp}$ & $215,421,753$ \\
\cline { 2 - 4 } & 2018 & $\mathrm{Rp}$ & $188,494,034$ \\
\hline
\end{tabular}

Adapun hasil perhitungan EUAC Capital untuk 15 tahun kedepan sebagai berikut:

Tabel 7 EUAC Capital 15 tahun kedepan

\begin{tabular}{|c|c|cc|}
\hline $\mathrm{n}$ & Tahun & \multicolumn{2}{|c|}{ EUAC Capital } \\
\hline 1 & 2019 & $\mathrm{Rp}$ & $164,932,280$ \\
\hline 2 & 2020 & $\mathrm{Rp}$ & $144,315,745$ \\
\hline 3 & 2021 & $\mathrm{Rp}$ & $126,276,277$ \\
\hline 4 & 2022 & $\mathrm{Rp}$ & $110,491,742$ \\
\hline 5 & 2023 & $\mathrm{Rp}$ & $96,680,274$ \\
\hline 6 & 2024 & $\mathrm{Rp}$ & $84,595,240$ \\
\hline 7 & 2025 & $\mathrm{Rp}$ & $74,020,835$ \\
\hline 8 & 2026 & $\mathrm{Rp}$ & $64,768,231$ \\
\hline 9 & 2027 & $\mathrm{Rp}$ & $56,672,202$ \\
\hline 10 & 2028 & $\mathrm{Rp}$ & $49,588,177$ \\
\hline 11 & 2029 & $\mathrm{Rp}$ & $43,389,654$ \\
\hline 12 & 2030 & $\mathrm{Rp}$ & $37,965,948$ \\
\hline 13 & 2031 & $\mathrm{Rp}$ & $33,220,204$ \\
\hline 14 & 2032 & $\mathrm{Rp}$ & $29,067,679$ \\
\hline 15 & 2033 & $\mathrm{Rp}$ & $25,434,219$ \\
\hline
\end{tabular}

\subsubsection{Perhitungan EUAC O\&M}

Perhitungan Equivalent Uniform Annual Cost O\&M ini dilakukan untuk memperhitungkan peningkatan biaya operational dan maintenance dengan mempertimbangkan jumlah biaya periode sebelumnya. Dalam perhitungannya melibatkan hasil penjumlahan operational cost dengan maintenance cost (O\&M) ditahun 2018 dan peningkatan (G) 
setiap tahunnya diasumsikan berdasarkan tingkat inflasi Bank Indonesia tahun 2018 sebesar 3.2\%, berikut hasil perhitungan jumlah operational cost dengan maintenance cost (O\&M) dan peningkatan biaya $(\mathrm{G})$ :

Tabel 8 Pertitungan Total O\&M dan G

\begin{tabular}{|c|cr|}
\hline $\begin{array}{c}\text { Operational } \\
\text { Cost }\end{array}$ & $\mathrm{Rp}$ & $555,018,960$ \\
\hline $\begin{array}{c}\text { Maintenance } \\
\text { Cost }\end{array}$ & $\mathrm{Rp}$ & $203,311,000$ \\
\hline Total O\&M & $\mathrm{Rp}$ & $758,329,960$ \\
\hline $\begin{array}{c}\text { Peningkatan } \\
\text { Inflasi 3.2\% }\end{array}$ & $\mathrm{Rp}$ & $24,266,559$ \\
\hline
\end{tabular}

Dengan menggunakan persamaan $\mathrm{O} \& \mathrm{M}+\mathrm{G}$ $(\mathrm{A} / \mathrm{G}, 10 \%, \mathrm{n})$ atau $\mathrm{Rp} 575,832,510+\mathrm{Rp}$ $18,426,640(\mathrm{~A} / \mathrm{G}, 10 \%, \mathrm{n})$ diperoleh hasil EUAC O\&M untuk 15 tahun kedepan sebagai berikut:

Tabel 9 Perhitungan EUAC Capital

\begin{tabular}{|c|c|}
\hline & EUAC O \& M \\
\hline $\mathrm{n}$ & $\begin{array}{c}\operatorname{Rp} 758,329,960+\operatorname{Rp} 24,266,599 \\
(\mathrm{~A} / \mathrm{G}, 10 \%, \mathrm{n})\end{array}$ \\
\hline 1 & $\operatorname{Rp} 758,329,960$ \\
\hline 2 & Rp 769,880,842 \\
\hline 3 & $\operatorname{Rp} 781,067,726$ \\
\hline 4 & $\operatorname{Rp} 791,842,078$ \\
\hline 5 & $\operatorname{Rp} 802,252,431$ \\
\hline 6 & $\operatorname{Rp} 812,298,787$ \\
\hline 7 & $\operatorname{Rp} 821,956,877$ \\
\hline 8 & $\operatorname{Rp} 831,226,702$ \\
\hline 9 & $\operatorname{Rp} 840,156,796$ \\
\hline 10 & Rp 848,722,891 \\
\hline 11 & $\operatorname{Rp} 856,949,255$ \\
\hline 12 & $\operatorname{Rp} 864,811,620$ \\
\hline 13 & $\operatorname{Rp} 872,358,519$ \\
\hline 14 & $\operatorname{Rp} 879,565,687$ \\
\hline 15 & $\operatorname{Rp} 886,433,123$ \\
\hline
\end{tabular}

\subsubsection{Perhitungan Total EUAC}

Perhitungan Total Equivalet Uniform Annual Cost pada penelitian ini untuk mengetahui total biaya yang dikeluarkan perusahaan dalam menggunakan mesin injeksi plastik setiap harus diterima perusahaan ketika mesin injeksi plastik mengalami kegagalan sebesar Rp 439,219,486 semakin besar peluang kegagalannya maka semakin besar risiko yang diterima perusahaan.

\section{Replacement Analysis}

Perhitungan Replacement Analysis didapatkan hasil perhitungan biaya yang harus dikeluarkan tahunnya. Total EUAC diperoleh dari hasil penjumlahan EUAC Capital dengan EUAC O\&M yang telah dapatkan pada bab sebelumnya yang perkirakan untuk 15 tahun kedepan dengan bertujuan untuk mengetahui sisa umur hidup dari mesin injeksi plastik dan waktu kebijakan penggantian mesin berdasarkan Total EUAC minimum. Hasil perhitungan Total EUAC dapat dilihat pada tabel berikut:

Tabel 10 Perhitungan Total EUAC

\begin{tabular}{|l|l|lr|}
\hline \multirow{2}{*}{$\begin{array}{c}\text { year } \\
(\mathrm{n})\end{array}$} & \multirow{2}{*}{$\begin{array}{c}\text { useful } \\
\text { life }\end{array}$} & \multicolumn{2}{|c|}{$\begin{array}{c}\text { Total EUAC } \\
\text { O\&M }\end{array}$} \\
\cline { 3 - 4 } 1 & 7 & $\mathrm{Rp}$ & $923,262,240$ \\
\hline 2 & 8 & $\mathrm{Rp}$ & $914,196,587$ \\
\hline 3 & 9 & $\mathrm{Rp}$ & $907,344,002$ \\
\hline 4 & 10 & $\mathrm{Rp}$ & $902,333,820$ \\
\hline 5 & 11 & $\mathrm{Rp}$ & $898,932,706$ \\
\hline 6 & 12 & $\mathrm{Rp}$ & $896,894,027$ \\
\hline 7 & 13 & $\mathrm{Rp}$ & $895,977,712$ \\
\hline 8 & 14 & $\mathrm{Rp}$ & $895,994,933$ \\
\hline 9 & 15 & $\mathrm{Rp}$ & $896,828,998$ \\
\hline 10 & 16 & $\mathrm{Rp}$ & $898,311,068$ \\
\hline 11 & 17 & $\mathrm{Rp}$ & $900,338,909$ \\
\hline 12 & 18 & $\mathrm{Rp}$ & $902,777,567$ \\
\hline 13 & 19 & $\mathrm{Rp}$ & $905,578,724$ \\
\hline 14 & 20 & $\mathrm{Rp}$ & $908,633,366$ \\
\hline 15 & 21 & $\mathrm{Rp}$ & $911,867,342$ \\
\hline & & & \\
\hline
\end{tabular}

\section{ANALISIS}

\section{Risk Based Maintenance}

Perhitungan Risk Based Maintenance didapatkan hasil perhitungan konsekuensi dan risiko yang diterima perusahaan akibat adanya kegagalan pada mesin injeksi plastik, diperoleh bahwa konsekuensi dan risiko yang

perusahaan dalam menggunakan mesin injeksi plastik atau disebut sebagai Total EUAC yang diperkirakan selama 15 tahun kedepan setelah tahun 2018. Hasil perhitungan menunjukkan bahwa nilai minimum dari Total EUAC terdapat pada tahun ke-7 yaitu sebesar Rp $895,977,712$. Sehingga Kebijakan perawatan yang harus dilakukann perusahaan adalah melakukan penggantian mesin injeksi plastik 
setelah beroperasi selama 7 tahun sejak tahun 2019 atau tepatnya dilakukan penggantian setelah tahun 2025. Hal ini juga berarti sisa umur hidup dari mesin injeksi plastik adalah selama 7 tahun operasi lagi setelah tahun 2018.

\section{KESIMPULAN}

Berdasarkan hasil penelitian dengan menggunakan metode Risk Based Maintenance dan Replacement Analysis dapat disimpulkan bahwa:

1. Risiko yang diterima perusahaan ketika mesin Injeksi Plastik mengalami kegagalan sebesar $\mathrm{Rp}$ 439,219,486. ebijakan waktu penggantian mesin Injeksi Plastik dilakukan setelah 7 tahun operasi.

2. Sisa umur hidup dari mesin Injeksi Plastik adalah 7 tahun.

3. Sisa umur hidup dari mesin Injeksi Plastik adalah 7 tahun.

\section{DAFTAR PUSTAKA}

Alhilman, J. et al. (2015) 'LCC Application for Estimating Total Maintenance Crew and Optimal Age of BTS Component', pp. 543-547.

Giatman, M. (2006) Ekonomi Teknik. Jakarta: PT Raja Ghafindo Persada.
Jiang, R. and Murthy, D. N. P. (2008) Maintenance: Decision Models for Management.

Khalifa, M., Khan, F. and Thorp, J. (2015) 'Risk-based maintenance and remaining life assessment for gas turbines', Journal of Quality in Maintenance Engineering, 21(1), pp. 100-111. doi: 10.1108/JQME-122012-0047.

Khan, F. I. and Haddara, M. R. (2004) 'Riskbased maintenance of ethylene oxide production facilities', Journal of Hazardous Materials. doi: 10.1016/j.jhazmat.2004.01.011.

Mobley, R. K., Higgins, L. R. and Wikoff, D. J. (2008) Maintenance Engineering Handbook, Tissue engineering Part C Methods. doi: 10.1089/ten.TEA.2010.0565.

Nakagawa, T. (2008) Advanced Reliability Models and Maintenance Policies. London: Springer London (Springer Series in Reliability Engineering). doi: 10.1007/978-1-84800-294-4.

Newnan, D. G., Eschenbach, T. G. and Lavelle, J. P. (2004) Economic Analysis Ninth Edition. 9th edn. New York: Oxford University Press. 